\title{
Effect of Immobilized Enzymes Naringinase and Tannase Produced from Aspergillus Sp. Isolate Mk156394 Isolated from Rotten Pomelo on Quality Characteristics of Citrus Limetta Juice and Process Optimization by Using Response Surface Methodology
}

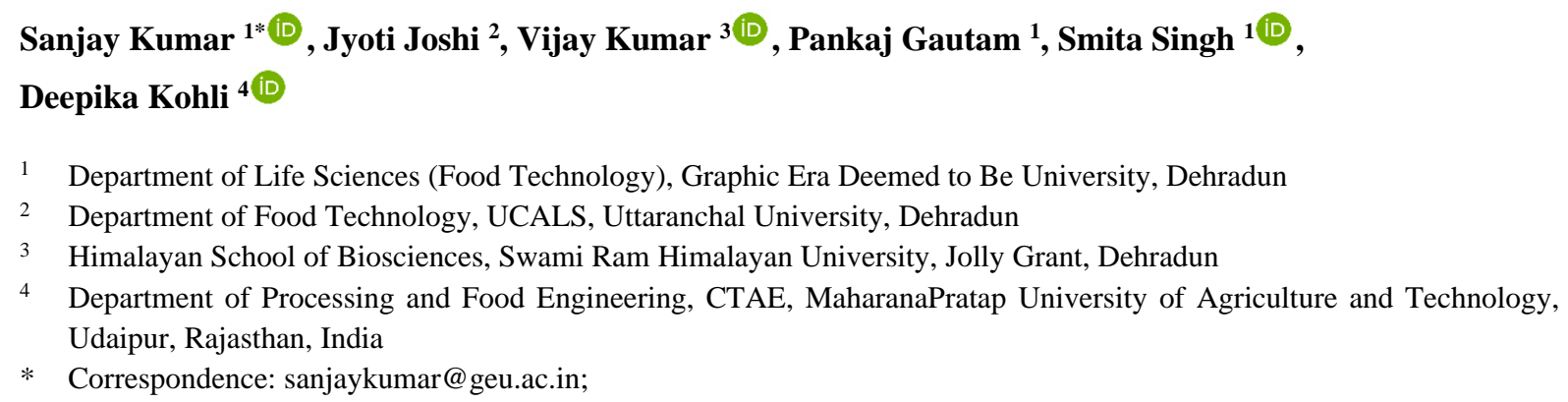

Received: 22.08.2020; Revised: 10.09.2020; Accepted: 12.09.2020; Published: 15.09.2020

\begin{abstract}
Enzymes naringinase and tannase were produced from Aspergillus sp. isolate mk156394 isolated from rotten pomelo, and the effect of both immobilized enzymes on quality characteristics of Citrus limetta juice has been investigated in this study. Total of 17 experiments were planned according to RSM-BBD. Enzyme ratio (naringinase: tannase) (100:0, 50:50, 0:100) and incubation temperature $\left(30^{\circ} \mathrm{C}, 40^{\circ} \mathrm{C}, 50^{\circ} \mathrm{C}\right)$ (each with three levels) were selected as the independent variables. The result of the study clearly indicated that independent variables affected the responses (Naringin content, Tannin content, TPC, and Vitamin C content). Design Expert 10.0.1 software was used to optimize the process parameters. The optimum values for process optimization were found to be 46.05 : $53.95,50^{\circ} \mathrm{C}$ and 4 hrs, and the optimum values for responses naringin content, tannin content, total phenolic content, and vitamin $\mathrm{C}$ content were found to be $225.367 \mu \mathrm{g} / \mathrm{ml}, 0.393 \mathrm{mg} / \mathrm{ml}, 1553.966 \mathrm{mg}$ GAE$/ \mathrm{L}, 34.713$ $\mathrm{mg} / 100 \mathrm{ml}$, respectively.
\end{abstract}

Keywords: naringinase; tannase; total phenolic content; immobilization

(C) 2020 by the authors. This article is an open-access article distributed under the terms and conditions of the Creative Commons Attribution (CC BY) license (https://creativecommons.org/licenses/by/4.0/).

\section{Introduction}

Citrus juices serve as an excellent source of highly potential bioactive compounds, especially antioxidants, which have the capability to scavenge free radicals produced inside the human body and also increase the defense mechanism of the body. This group of antioxidants mainly contains phenolic compounds, ascorbic acid, pectins, and flavonoids [1-2], which help in the replenishment of lost energy. Mosambi (Citrus limetta) is a member fruit of Rutaceae family[3]. It is a very valuable fruit for its medicinal and nutritional properties throughout the world [4]. It is a species of citrus, which is also known as sweet lime, sweet lemon, and sweet limetta. Some of the health benefits of mosambi are it aids digestion, relieves constipation, prevents scurvy as it contains vitamin $\mathrm{C}$, peptic ulcers, respiratory problems, improves the immune system, contains anti-cancer properties, protection against rheumatoid arthritis, 
facilitates weight loss, good for skin and hairs and many more. Besides being this much nutritious to human health mosambi juices is not widely processed at the industrial level due to its bitterness, which adversely affects its marketability. Also, upon the longer duration of the storage period of the juices, due to tannin content, certain factors such as sedimentation, haziness, color, astringency, and bitterness get increased [5,6]. These problems can be solved by using the enzymes naraginase and tannase. Naringin gets hydrolyzed to naringenin by the application of enzyme naringinase. Naringenin is a non-bitter derivative of naringin, i.e., chemically 4,5,7-trihydroxyflavonone, and it could not be re-converted to naringin [7,8] and glucose [9-11] and in turn, it leads to the enhancement in the taste of the citrus juices [12]. According to the study conducted by [13] and [14], naranginase could be utilized for the modification of flavonoids in order to yield bioactive compounds with maximum health enriching potential. Similarly, tannins have been utilized for the production of gallic acid. This has been possible by the application of tannase enzyme (EC 3.1.1.20), also chemically known as tannin acyl hydrolase, over the substrates. This enzyme has found its role in various applications world-wide, especially in pharmaceuticals, tannery, alcohol industries, and beverages [15].

Therefore, the present study has been focused on analyzing the effect of immobilized enzymes naringinase and tannase produced from Aspergillus sp. isolate MK156394 isolated from rotten pomelo on physicochemical characteristics, i.e., naringine content, tannin content, total phenolic content, and vitamin $\mathrm{C}$ content of Citrus limetta juice.

\section{Materials and Methods}

\subsection{Raw materials.}

Citrus limetta of sound quality was brought from the local market of Dehradun, and the juice was prepared in the Department's laboratory under proper hygienic conditions. The prepared juice was kept at $4{ }^{\circ} \mathrm{C}$, i.e., the refrigeration temperature for conduction of further analysis. Enzymes naringinase and tannase were produced through submerged fermentation from Aspergillus sp. isolate Mk156394 and partially purified by ammonium sulfate (80\%) ppt method. The activity of partially purified enzyme naringinase and tannase was $1.63 \mathrm{IU} / \mathrm{ml}$ and $1.18 \mathrm{IU} / \mathrm{ml}$, respectively. The chemicals used in this study were of analytical grade and purchased from Hi-Media.

\subsection{Production of enzymes.}

Enzymes naringinase and tannase were produced through submerged fermentation by the method of [16,17], respectively, from Aspergillus sp. isolate Mk156394 and partially purified by ammonium sulfate $(80 \%)$ ppt method. Naringinase activity was assayed with respect to naringin using the method of Davis [18] with little modification. Tannase activity was determined calorimetrically using the method of [19]. The activity of partially purified crude enzymes naringinase and tannase was $1.63 \mathrm{IU} / \mathrm{ml}$ and $1.18 \mathrm{IU} / \mathrm{ml}$, respectively.

\subsection{Immobilization of naringinase.}

Immobilization of Naringinase was done by [20] with some modifications. Briefly, A $5 \mathrm{ml}$ suspension containing crude naringinase at a concentration of $1 \mathrm{~g} / 1$ and 3\% sodium alginate was extruded into a $0.2 \mathrm{M} \mathrm{CaCl}_{2}$ solution at a temperature of $4^{\circ} \mathrm{C}$ to form the gel beads. 
After $4 \mathrm{~h}$, the beads were washed 2-3 times with $0.1 \mathrm{M}$ sodium acetate buffer, $\mathrm{pH} 4.0$, and used for naringinase assay.

\subsection{Immobilization of tannase.}

The immobilization of tannase was done by the method previously described with some modifications [21]. Briefly, A $5 \mathrm{ml}$ suspension containing tannase at a concentration of $1 \mathrm{~g} / 1$ and $3 \%$ sodium alginate was extruded into a $0.2 \mathrm{M} \mathrm{CaCl}_{2}$ solution at a temperature of $4{ }^{\circ} \mathrm{C}$ to form the gel beads. After $4 \mathrm{~h}$, the beads were washed 2-3 times with water and kept at $4^{\circ} \mathrm{C}$.

\subsection{Identification and selection of the most important variables.}

Enzyme ratios were selected to show the effect of naringinase and tannase individually or in a combination of both on quality characteristics of Citrus limetta juice as an individual or in a combination of both. The enzyme ratios range (100:0, 50:50, 0:100) were selected. Based on preliminary experiments, incubation temperature $\left(30^{\circ} \mathrm{C}, 40^{\circ} \mathrm{C}, 50^{\circ} \mathrm{C}\right)$ and incubation time $(2,3,4 \mathrm{hrs})$ were selected as variables.

\subsection{Physiochemical analysis.}

$\mathrm{pH}$ was measured by handy $\mathrm{pH}$ meter (Eutech), TSS was measured by using a hand refractometer (ERMA), Titrable acidity was measured by [22], Vitamin C (mg/100ml) was measured by the method of [23]. Total Phenolic Content (mg GAE/L) was measured as described $[24,25]$. Tannin content $(\mathrm{mg} / \mathrm{ml})$ and naringin content $(\mu \mathrm{g} / \mathrm{ml})$ in Citrus limetta juice were determined by the method of $[26,18]$, respectively.

\subsection{Statistical analysis.}

Design-Expert 10.0.1 was used for data analysis and process optimization. To evaluate the effect of process parameters, i.e., enzyme ratios (naringinase: tannase), incubation temperature $\left({ }^{\circ} \mathrm{C}\right.$ ), and incubation time (hrs.) on the responses, i.e., naringin content, tannin content, TPC, and vitamin C content, a second-order response function was implemented for three independent variables having following general form of Equation 1.

$$
\mathrm{Y}=\beta_{0}+\sum_{\mathrm{i}=1}^{3} \beta_{\mathrm{i}} \mathrm{X}_{\mathrm{i}}+\sum_{\mathrm{i}=1}^{2} \sum_{j=\mathrm{i}+1}^{3} \beta_{\mathrm{ij}} \mathrm{X}_{\mathrm{i}} \mathrm{X}_{j}+\sum_{\mathrm{i}=1}^{3} \beta_{\mathrm{ii}} \mathrm{X}_{\mathrm{i}}^{2}
$$

Where,

$\mathrm{Y}=$ Response

$\beta_{0}, \beta_{\mathrm{ii}}, \beta_{\mathrm{ij}}=$ Coefficients

$\mathrm{X}_{\mathrm{i}}$ and $\mathrm{X}_{\mathrm{j}}=$ Independent Variables

ANOVA was used for determining the statistical significance of the independent parameters and their relative interactions. The model's adequacy was explained in terms of $\mathrm{R}^{2}$ (coefficient of determination), F-value (Fisher's value), and LOF (lack-of-fit). For materials, see the policy of the journal.

\section{Results and Discussion}

A total of 17 experiments were designed by using the Box-Benkhen design of RSM. These runs were performed to see the effect of the selected process parameters- enzyme ratio, 
temperature \& time on the said responses, i.e., naringin content, tannin content, TPC, and vitamin $\mathrm{C}$. The results were statistically analyzed for being either significant or non-significant. The results of the experiment are given in Table 1. Table 2 and Table 3 shows the ANOVA and regression analysis that was performed in order to check the model's adequacy.

Table 1 shows the respective effect of the process parameters on responses or quality characteristics, i.e., naringin content, tannin content, TPC, and vitamin C of Citrus limetta Juice. The results of the experiment are given in Table 1. ANOVA (analysis of variance) and regression analysis were used to check the adequacy of the model, as shown in Table 2 and Table 3, respectively.

For the regression model, the goodness of fit was measured by the correlation coefficient $(\mathrm{R})$. $\mathrm{R}^{2}$ (coefficient of determination) in the case of the regression model for Naringin content, Tannin content, TPC, and Vitamin C content was 0.8751,0.9917,0.8713 and 0.9710 , respectively (Table 3). The authenticity of the regression model, which explained the reaction properly, was clear from the $\mathrm{R}^{2}$ value, i.e., 0.90 for the response variable. However, lack of fit was found to be insignificant, and hence, the second-order model was found adequate for describing all the responses.

Table 1. Experimental design and experimental results of Citrus limetta juice.

\begin{tabular}{|c|c|c|c|c|c|c|c|}
\hline \multirow[t]{2}{*}{ Exp. No. } & \multicolumn{3}{|c|}{ Variables } & \multicolumn{4}{|c|}{ Responses } \\
\hline & $\begin{array}{c}\text { Enzymes Blend } \\
\text { ratios } \\
\text { (Naringinase: } \\
\text { Tannase) }\end{array}$ & $\begin{array}{c}\text { Temp. } \\
\left({ }^{\circ} \mathrm{C}\right)\end{array}$ & $\begin{array}{c}\text { Time } \\
\text { (hrs) }\end{array}$ & $\begin{array}{c}\text { Naringin } \\
\text { content } \\
(\mu \mathrm{g} / \mathrm{ml})\end{array}$ & $\begin{array}{l}\text { Tannin } \\
\text { content } \\
(\mathrm{mg} / \mathrm{ml})\end{array}$ & $\begin{array}{c}\text { Total } \\
\text { phenolic } \\
\text { content } \\
\text { mgGAE/L }\end{array}$ & $\begin{array}{c}\text { Vitamin C } \\
\text { content } \\
(\mathrm{mg} / 100 \mathrm{ml})\end{array}$ \\
\hline 1 & $100: 0$ & 30 & 3 & 365.7 & $0.59 * *$ & 2067.6 & 28.2 \\
\hline 2 & $0: 100$ & 30 & 3 & 434.04 & 0.54 & 2038.4 & 15.2 \\
\hline 3 & $100: 0$ & 50 & 3 & 210.39 & 0.5 & 1718.3 & 17.4 \\
\hline 4 & $0: 100$ & 50 & 3 & 445.5 & 0.4 & 1896.5 & 14.4 \\
\hline 5 & 100:0 & 40 & 2 & 301.68 & 0.55 & 1985.1 & 22.2 \\
\hline 6 & $0: 100$ & 40 & 2 & 414.38 & 0.52 & 1659.6 & 21.5 \\
\hline 7 & $100: 0$ & 40 & 4 & 311.79 & 0.58 & 2052.7 & 18.4 \\
\hline 8 & $0: 100$ & 40 & 4 & $457.86^{* *}$ & 0.45 & 1989.7 & $13.8^{*}$ \\
\hline 9 & $50: 50$ & 30 & 2 & 412.92 & 0.51 & 1802.5 & $39.2 * *$ \\
\hline 10 & $50: 50$ & 50 & 2 & 234.04 & 0.45 & $2102.9 * *$ & 38.7 \\
\hline 11 & $50: 50$ & 30 & 4 & 216.91 & 0.53 & 1955.4 & 38.2 \\
\hline 12 & $50: 50$ & 50 & 4 & $189.97^{*}$ & $0.39^{*}$ & 1493.3 & 37.1 \\
\hline 13 & $50: 50$ & 40 & 3 & 351.68 & 0.48 & 1541.2 & 38.4 \\
\hline 14 & $50: 50$ & 40 & 3 & 361.97 & 0.47 & 1327.6 & 35.2 \\
\hline 15 & $50: 50$ & 40 & 3 & 305.68 & 0.49 & 1321.6 & 34.5 \\
\hline 16 & $50: 50$ & 40 & 3 & 315.54 & 0.48 & 1390.2 & 36.2 \\
\hline 17 & $50: 50$ & 40 & 3 & 303.97 & 0.49 & $1320.6^{*}$ & 35.4 \\
\hline
\end{tabular}

Table 2. ANOVA for different responses.

\begin{tabular}{|c|c|c|c|c|}
\hline \multirow[t]{2}{*}{ Sources } & \multicolumn{4}{|c|}{ F-values of responses } \\
\hline & $\begin{array}{c}\text { Naringin content } \\
(\mu \mathrm{g} / \mathrm{ml})\end{array}$ & $\begin{array}{c}\text { Tannin content } \\
(\mathrm{mg} / \mathrm{ml})\end{array}$ & $\begin{array}{c}\text { TPC } \\
\text { mgGAE/L }\end{array}$ & $\begin{array}{c}\text { Vitamin C content } \\
(\mathrm{mg} / 100 \mathrm{ml})\end{array}$ \\
\hline Model & $5.45^{* *}$ & $92.60 * * *$ & $5.27 * *$ & $26.06 * * *$ \\
\hline Linear & $9.546 * * *$ & $205.668 * * *$ & 0.083 & $5.274 * *$ \\
\hline Quadratic & $4.953 * *$ & $4459.039 * * *$ & $12.255 * * *$ & $72.050 * * *$ \\
\hline Interactive & 2.098 & $27.220 * * *$ & $13804.28 * * *$ & 1.474 \\
\hline Lack of fit (LOF) & $5.21(\mathrm{NS})$ & 0.60 (NS) & $5.25(\mathrm{NS})$ & $5.42(\mathrm{NS})$ \\
\hline
\end{tabular}
**, *** significant at 1 and $5 \%($ LOS $)$, respectively

Table 2 obtained from ANOVA clearly shows that the models formed were highly significant with a good fit of the model. F-value of naringin content, tannin content, TPC, and vitamin $\mathrm{C}$ content was calculated to be 5.45,92.60,5.27,26.06 at 1\%,5\%,1\%,5\% level of significance, respectively, showing that all the models were found to be extremely significant statistically. 
Table 3. Coefficients for different responses by design Expert 10.0.1.

\begin{tabular}{|c|c|c|c|c|}
\hline \multirow[t]{2}{*}{ Factor } & \multicolumn{4}{|c|}{ Coefficients } \\
\hline & $\begin{array}{l}\text { Naringine } \\
\text { Content }(\mu \mathrm{g} / \mathrm{ml})\end{array}$ & $\begin{array}{l}\text { Tannin Content } \\
(\mathrm{mg} / \mathrm{ml})\end{array}$ & $\begin{array}{l}\text { TPC } \\
\text { (mgGAE/L) }\end{array}$ & $\begin{array}{l}\text { Vit C } \\
\text { Content } \\
(\mathrm{mg} / 100 \mathrm{ml})\end{array}$ \\
\hline Intercept & 327.768 & 0.482 & 1380.24 & 35.94 \\
\hline $\begin{array}{c}X_{1} \\
\text { Enzyme Ratio (Nringinase: } \\
\text { Tannase) } \\
\end{array}$ & $70.2775 * * *$ & $-0.03875 * * *$ & -29.937 & $-2.6625 * *$ \\
\hline $\begin{array}{c}\mathbf{X}_{2} \\
\text { (Incubation Temperature) }\end{array}$ & $-43.7087 * *$ & $-0.05375 * * *$ & -81.6125 & -1.65 \\
\hline $\begin{array}{c}\mathrm{X}_{3} \\
\text { (Incubation Time) } \\
\end{array}$ & -23.3113 & $-0.01 * * *$ & -7.375 & -1.7625 \\
\hline $\mathrm{X}_{1} \mathrm{X}_{2}$ & 41.6925 & $-0.0125 * *$ & 51.85 & 2.5 \\
\hline$X_{1} X_{3}$ & 8.3425 & $-0.025 * * *$ & 65.625 & -0.975 \\
\hline $\mathbf{X}_{2} \mathbf{X}_{3}$ & 37.985 & $-0.02 * * *$ & $-190.625 * *$ & -0.15 \\
\hline$X_{1}^{2}$ & $72.0535 * *$ & $0.04025^{* * *}$ & $316.605 * * *$ & $-18.2325 * * *$ \\
\hline$X_{2}^{2}$ & -35.914 & $-0.01475 * * *$ & $233.355 * *$ & 1.0925 \\
\hline $\mathrm{X}_{3}^{2}$ & -28.394 & 0.00275 & $224.93 * *$ & 1.2675 \\
\hline $\mathbf{R}^{2}$ & 0.8751 & 0.9917 & 0.8713 & 0.9710 \\
\hline
\end{tabular}

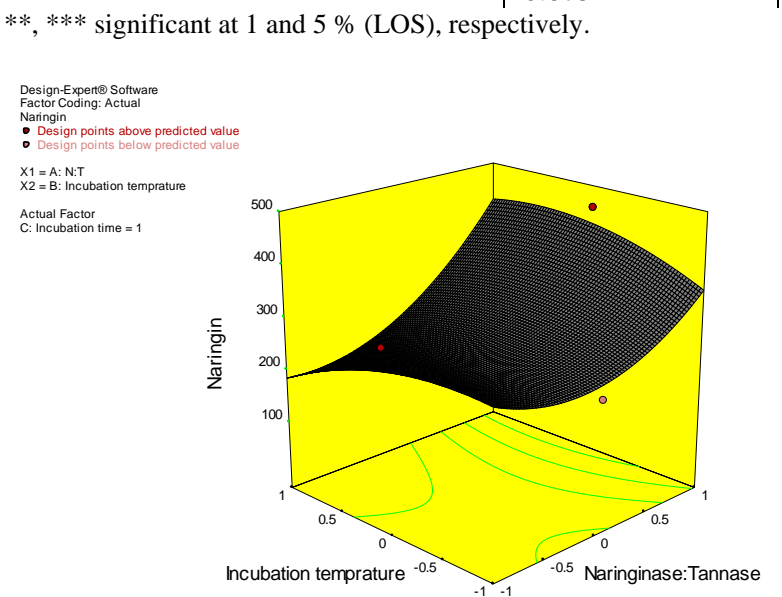

(a)

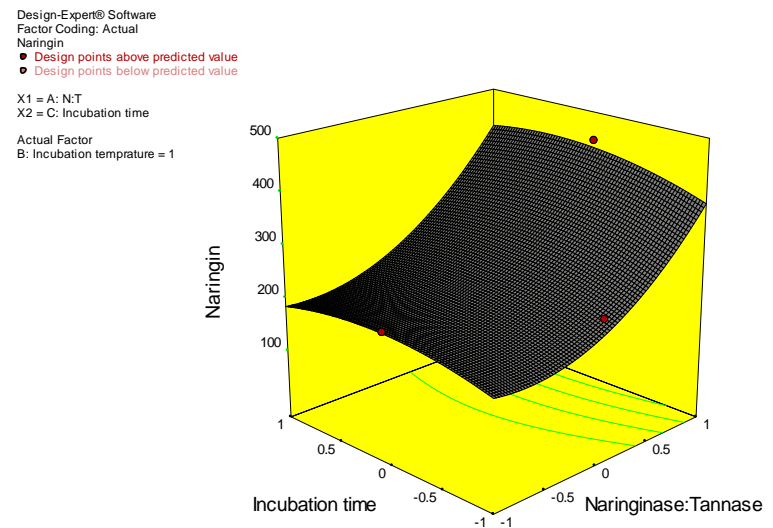

(b)

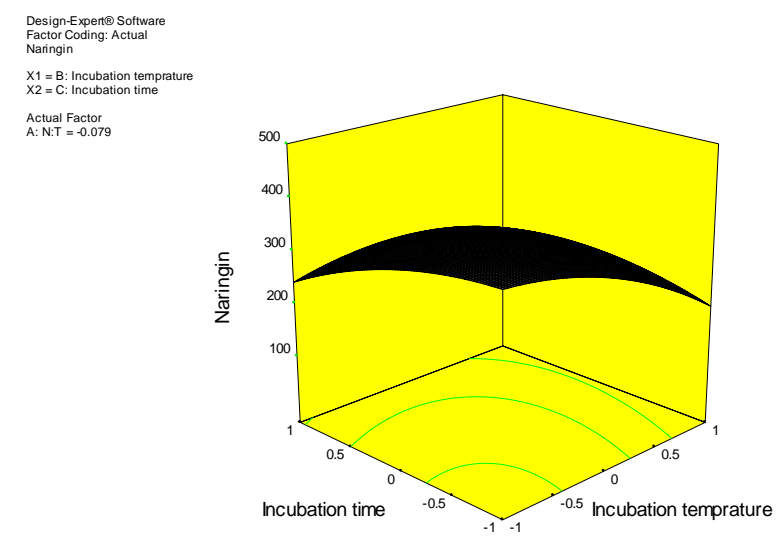

(c)

Figure 1. Response surface showing interaction effect of process parameters (a) temperature \& enzyme ratio (b) time \& enzyme ratio (c) time \& temperature on naringin content.

\subsection{Effect on Naringin content.}

For the analysis of naringin content, from Table 2, it was concluded that the linear term was found to be significant at $5 \%(\mathrm{P} \leq 0.05)$ however; the quadratic term was at $1 \%(\mathrm{P} \leq 0.01)$ level of significance. From Table 3 of coefficient, it was found that $\mathrm{X}_{1}$ (enzyme ratio) had a positive effect on naringin content showed at linear and quadratic level with LOS at $1 \%$ 
$(\mathrm{p} \leq 0.01)$ and $5 \%(\mathrm{p} \leq 0.05)$, respectively, while $\mathrm{X}_{2}$ (Temperature) and $\mathrm{X}_{3}$ (Time) had a negative effect at $5 \%(\mathrm{p} \leq 0.05)$ and more than $10 \%(\mathrm{p}<0.1)$ LOS, respectively. The response surfaces are represented by Figure $1(\mathrm{a}, \mathrm{b}, \mathrm{c})$.

From Figure 1 (a), it was clearly observed that naringin content decreased as incubation temperature increased $\left(30\right.$ to $50^{\circ} \mathrm{C}$ ) with constant incubation time. Naringin content also decreased up to the central value of enzyme ratio (50:50), and after that increased, Figure 1(b) showed the increase pattern of naringin content value as time and enzyme ratio increased; figure 1 (c) clearly depicted that the naringin content decreased as time and temperature increased. Similar studies were also reported by [27-29] who observed that the naringin content in grapefruit juice and pomelo juice got decreased when the juice sample was treated with naringinase.

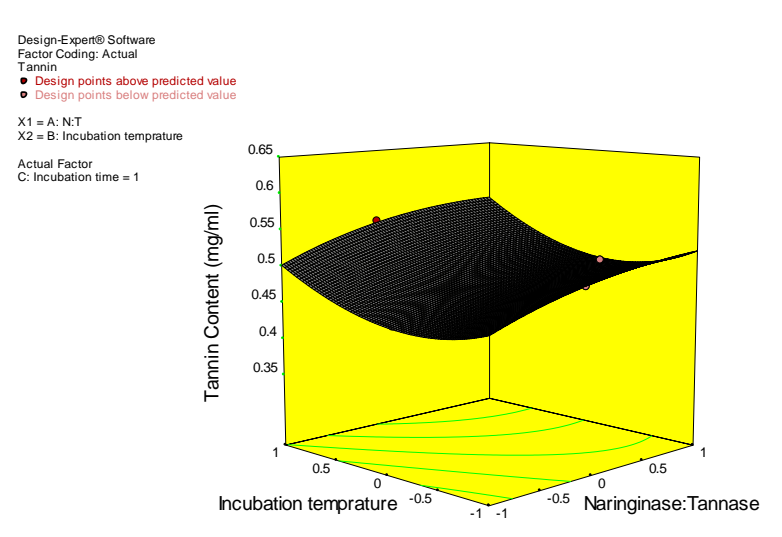

(a)

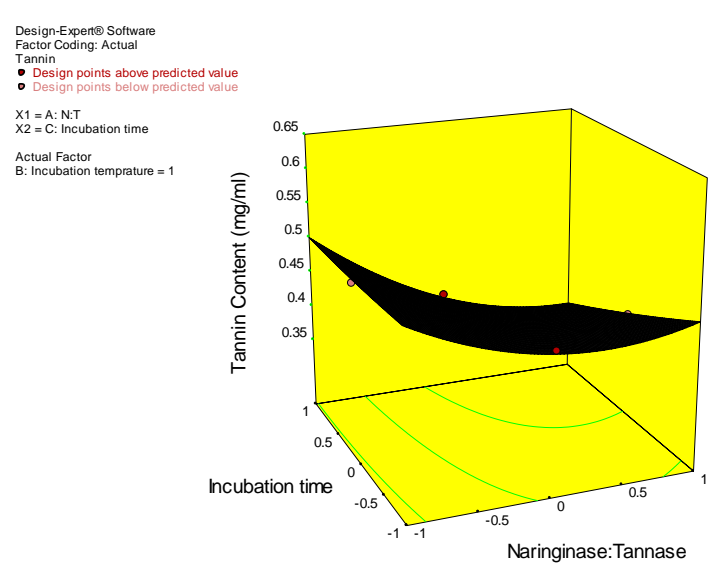

(b)

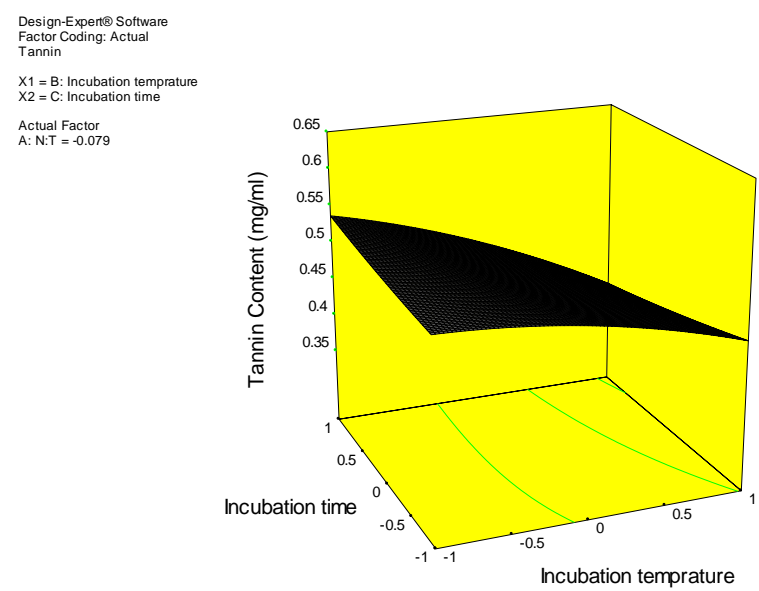

(c)

Figure 2. Response surface showing the interaction effect of process parameters (a) enzyme ratio and temperature (b) enzyme ratio and time (c) temperature and time on tannin content.

\subsection{Effect on Tannin content.}

For tannin content, from Table 2, it was observed that all three linear, quadratic, and interactive term was found to be significant at $\operatorname{LOS}$ at $5 \%(\mathrm{P} \leq 0.05)$. From Table 3 of coefficient, it was found that $\mathrm{X}_{1}$ (enzyme ratio), $\mathrm{X}_{2}$ (Temperature), and $\mathrm{X}_{3}$ (Time) had a negative effect on tannin content at linear level with LOS at $\%(\mathrm{p} \leq 0.01)$. At the quadratic level $\mathrm{X}_{1}$ (enzyme ratio) and $\mathrm{X}_{2}$ (Temperature) had a positive and negative effect on tannin content with LOS at $1 \%(\mathrm{p} \leq 0.01)$, respectively. $\mathrm{X}_{1}$ (enzyme ratio), $\mathrm{X}_{2}$ (Temperature), and $\mathrm{X}_{3}$ (Time) had a negative effect on tannin content at an interactive level at LOS with $5 \%(\mathrm{P} \leq 0.05)$ and $1 \%(\mathrm{p} \leq 0.01)$, respectively. Figure $2(\mathrm{a}, \mathrm{b}, \mathrm{c})$ shows the response surface for tannin content. 
Figure 2 (a) clearly shows that tannin content was found to be in a decreasing manner, w.r.t the increasing temperature and enzyme ratio. It is observed from Figure 2 (b) that as there was an increase in time and enzyme ratio, tannin content decreased significantly. From Figure 2 (c), it is clearly depicted that the tannin content decreased as temperature increased. ElTanash [30] and Rout and Banerjee [6] also reported similar results in their study.

\subsection{Effect on total phenolic content.}

For total phenolic content, it was clearly observed from Table 2 that quadratic and interactive term was significant at LOS, i.e., $1 \%(\mathrm{P} \leq 0.01)$. From Table 3 it was observed that $\mathrm{X}_{1}$ (enzyme ratio), $\mathrm{X}_{2}$ (Temperature), and $\mathrm{X}_{3}$ (time) had a positive effect on total phenolic content at the quadratic level with $\operatorname{LOS}$ at $1 \%(\mathrm{P} \leq 0.01)$ and $5 \%(\mathrm{P} \leq 0.05)$ while $\mathrm{X}_{2}$ (Temperature) and $\mathrm{X}_{3}$ (Time) had a negative effect on total phenolic content at interactive level with the level of significance at $5 \%(\mathrm{P} \leq 0.05)$. Figure $3(\mathrm{a}, \mathrm{b}, \mathrm{c})$ shows the response surface for total phenolic content.

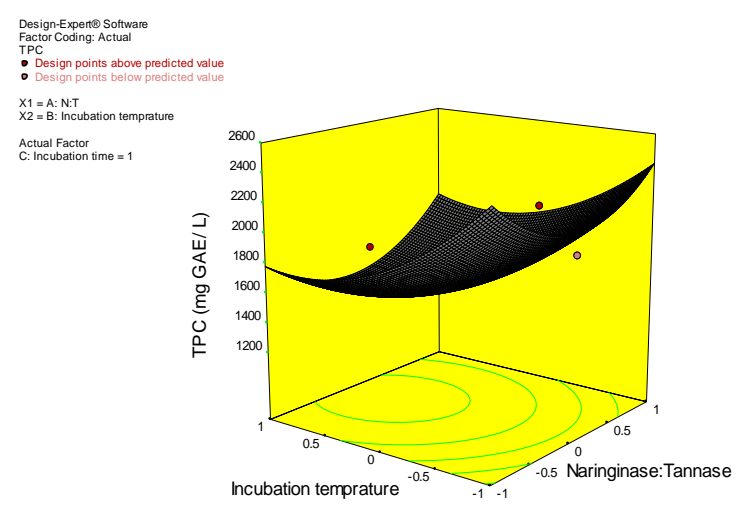

(a)

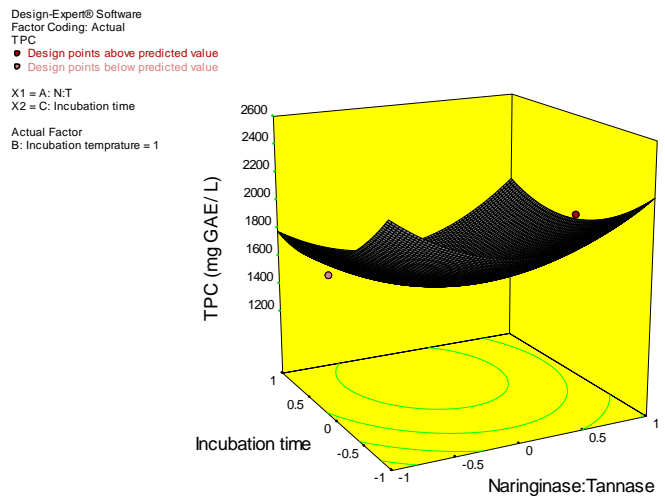

(b)

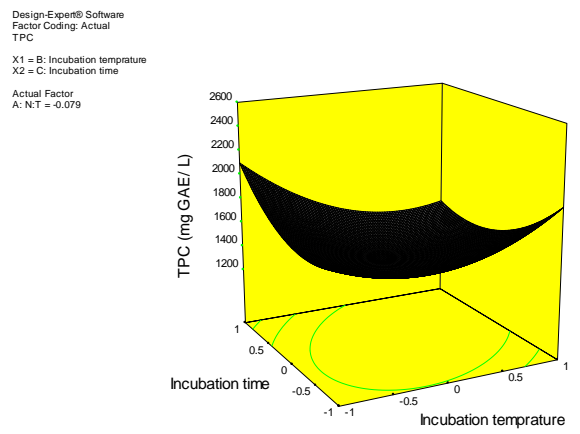

(c)

Figure 3. Response surface showing the interaction effect of process parameters (a) temperature and enzymeratio (b) time and enzyme ratio (c) time and temperature on total phenolic content (TPC).

From Figure 3 (a) and 3 (b), it was clearly observed that total phenolic content was highest at low temperature and time when the only naringinase is present in enzyme ratio. From Figure 3 (c), an increased pattern in total phenolic content values was observed with increased time and temperature. This increment in total phenolic content could be co-related with the presence of naringenin (i.e., a metabolite produced from naringin with hydroxyl groups) or, due to the possibility of overestimation of polyphenolic content w.r.t lack of selectivity of Folin-Ciocalteu's reagent [31], when analyzed through the spectrophotometric method. It also shows that Folin-Ciocalteu's reagent reacts with reducing compounds like sugars (e.g., glucose) and not only reacts with phenols [32]. Our findings favor the findings of Cavia-Saiz 
[33], who observed that the total phenolic content was increased as the naringinase concentration increases.

\subsection{Effect on Vitamin C content.}

For vitamin $\mathrm{C}$, it was clearly observed from Table 2 that linear and quadratic terms were found to be significant at LOS, i.e., $1 \%(\mathrm{P} \leq 0.01)$ and 5\% $(\mathrm{P} \leq 0.05)$, respectively. From Table 3 , it was observed that only $\mathrm{X} 1$ (enzyme ratio) had a positive effect on vitamin $\mathrm{C}$ content at LOS, i.e., $1 \%(\mathrm{p} \leq 0.01)$ and $5 \%(\mathrm{P} \leq 0.05)$, respectively, at a quadratic and linear level. The response surface showing the vitamin $\mathrm{C}$ content is depicted in Fig. 4 (a, b, c).

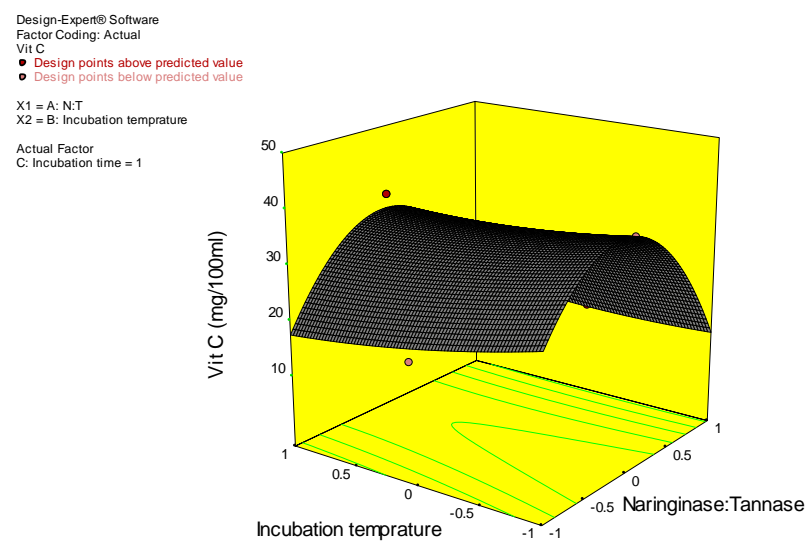

(a)

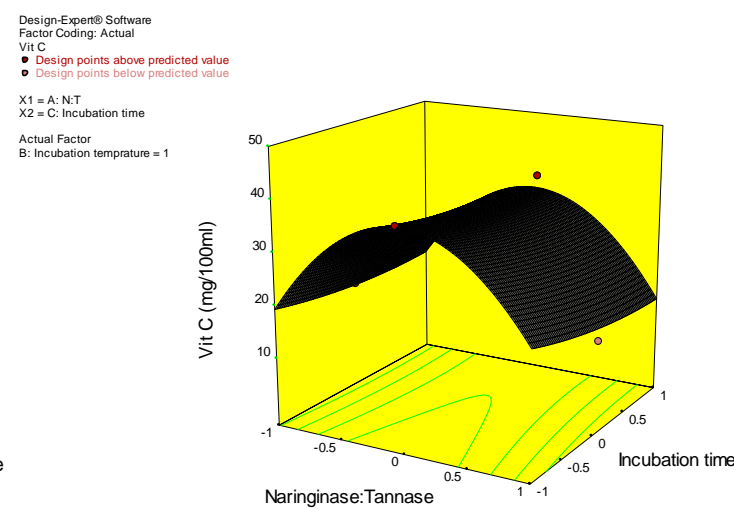

(b)

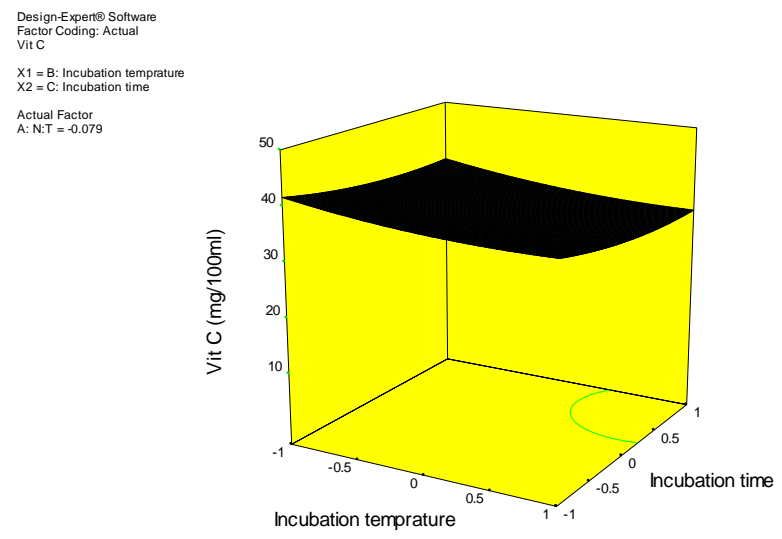

(c)

Figure 4. Response surface showing interaction effect of process parameters (a) temperature \& enzyme ratio (b) time \& enzyme ratio (c) time \& temperature on vitamin $\mathrm{C}$.

Fig 4 (a) shows that as temperature increases vitamin $\mathrm{C}$ content was decreased with enzyme ratio. Vitamin $\mathrm{C}$ content was found to decrease significantly, with the increase in time and enzyme ratio (Fig. 4b).

However, Figure 4(c) showed that with the increase in time and temperature, vitamin $\mathrm{C}$ content was found to be decreased. High temperature leads to the denaturation of enzymes, which shows the possible reason for the decrease of vitamin C content. Sawinder et al. [32] also reported a similar result, i.e., with the increase in temperature, ascorbic acid content tends to decrease. 

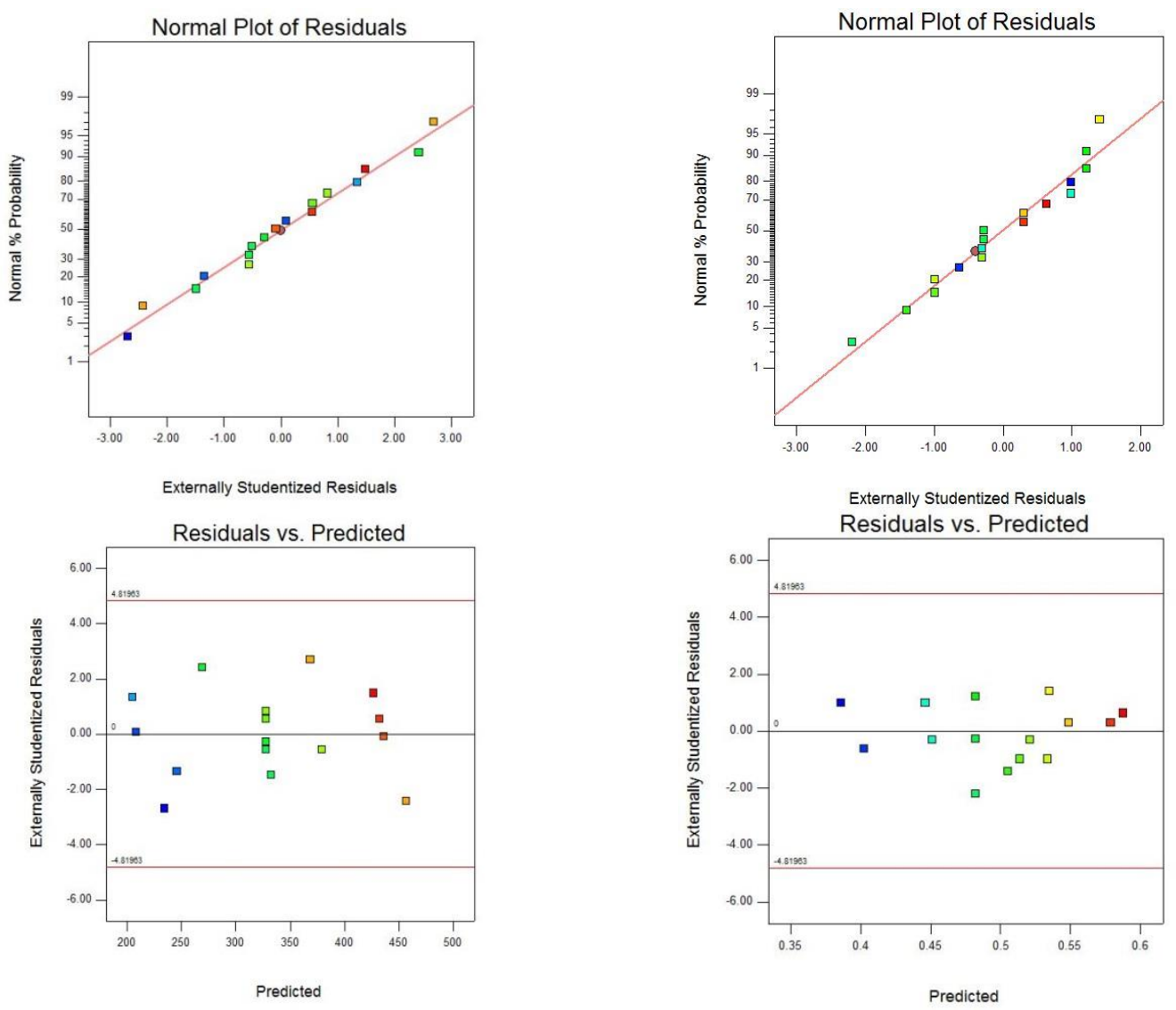

Figure 5. (a) Normal plot of residual and residual vs. predicted values plot of naringin content.

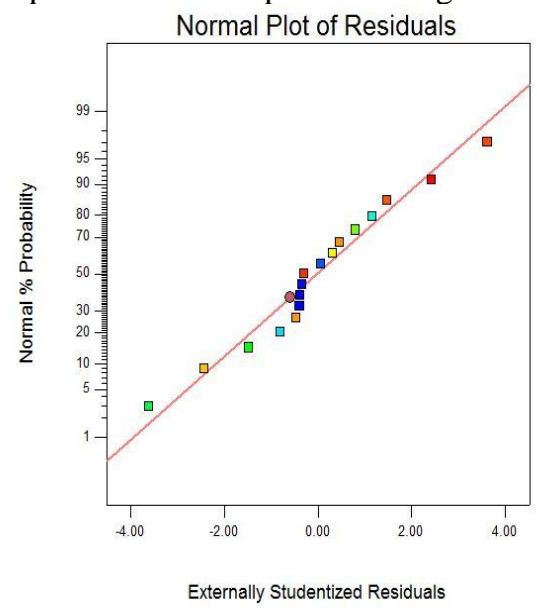

Figure 5. (b) Normal plot of residual and residual vs. predicted values plot of tannin content.
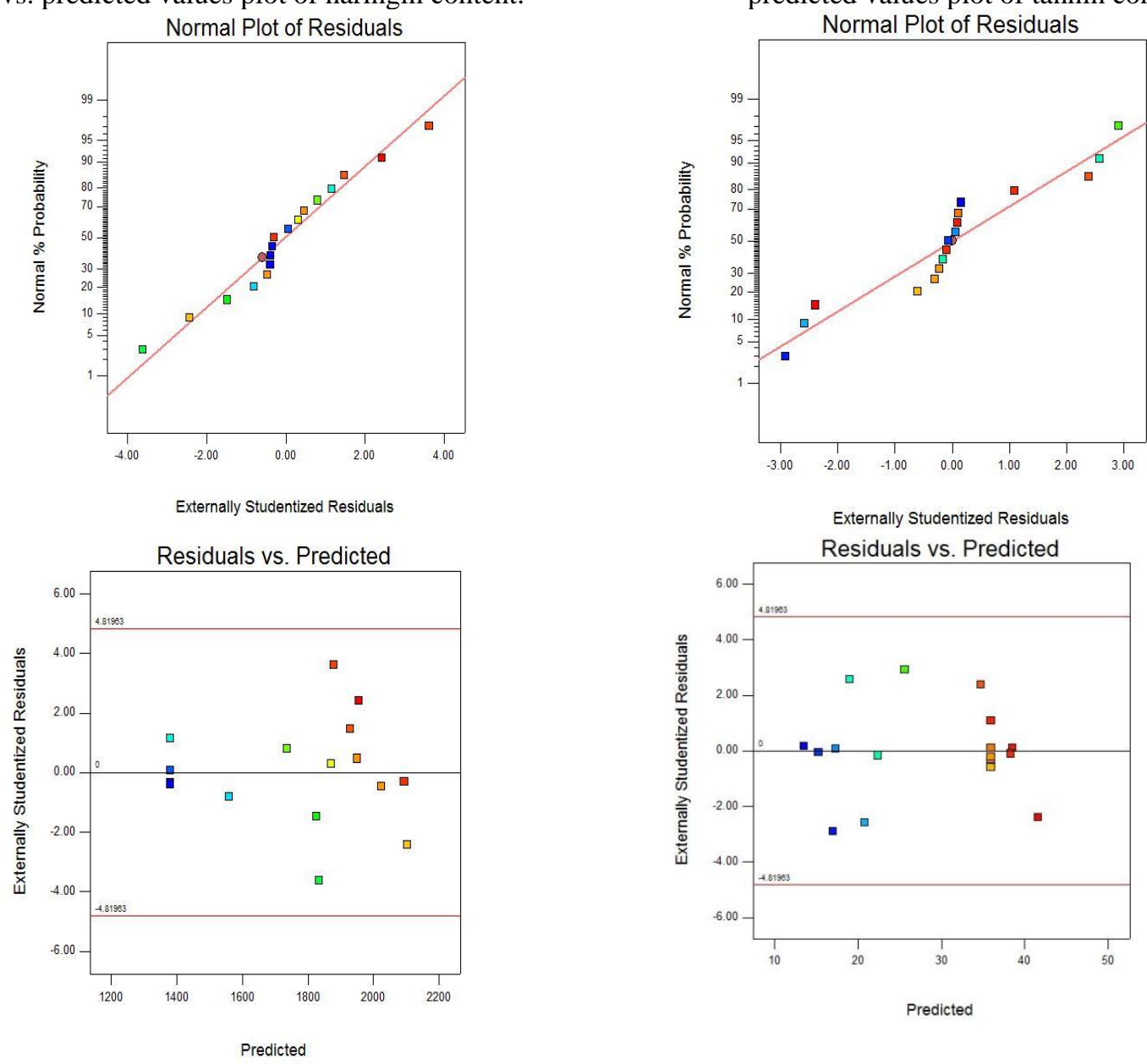

Figure 5. (c) Normal plot of residual and residual vs. predicted values plot of TPC

Figure 5. (d) Normal plot of residual and residual vs. predicted values plot of Vitamin C content. 


\subsection{Model confirmation.}

The residual plot method was used for analyzing the effect of immobilized enzymes naringinase and tannase on the quality characteristics of Citrus limetta juice. From the normal plot of Figures 5 (a), (b), (c), and (d), it has been shown that points are clustered consecutively in the region of the straight line, therefore suggesting that it is followed by a normal distribution and no other deviation was observed from the straight line of all the plots shown here. Additionally, the response models could be able to predict the actual values.

However, any clear pattern was not obtained between the residual plot and predicted plot. The results obtained were distributed in a shuffling manner that clearly affirms the model adequacy.

\section{Conclusion}

A significant effect was observed upon the application of the immobilized enzymes naringinase and tannase, which is produced from Aspergillus sp. isolate MK156394 isolated from rotten pomelo on the quality characteristics of Citrus limetta juice. The optimum values were found to be $46.05: 53.95,50^{\circ} \mathrm{C}$, and $4 \mathrm{hrs}$. The optimum values for naringin content, tannin content, TPC and vitamin C content were found to be $225.367 \mu \mathrm{g} / \mathrm{ml}, 0.393 \mathrm{mg} / \mathrm{ml}$, $1553.966 \mathrm{mg} \mathrm{GAE} / \mathrm{L}, 34.713 \mathrm{mg} / 100 \mathrm{ml}$, respectively. This study revealed that the bittering compounds naringin and tannase present in Citrus limetta juice could be minimized by using immobilized enzymes produced from Aspergillus sp. isolate MK156394 and improve the organoleptic quality also. It could also be concluded that enzymes produced from Aspergillus $s p$. isolate MK156394 can be used at the industrial level to improve the quality characteristics of other citrus juices.

\section{Funding}

This research received no external funding.

\section{Acknowledgments}

The authors are grateful to the Department of Life Sciences, Graphic Era (Deemed-to-be) University, Dehradun, Uttarakhand, India, for permitting us to carry out the study at the University.

\section{Conflicts of Interest}

The authors declare no conflict of interest.

\section{References}

1. Ebrahimzadeh, M.A.; Hosseinimehr, S.J.; Gayekhloo, M.R. Measuring and comparison of vitamin C content in citrus fruits: Introduction of native variety. Chemistry: An Indian Journal 2004, 1, 650-652.

2. Jayaprakasha, G.K.; Patil, B.S. In vitro evaluation of the antioxidant activities in fruit extracts from citron and blood orange. Food Chemistry 2007, 101, 410-418, https://doi.org/10.1016/j.foodchem.2005.12.038

3. Mondal, N.K.; Basu, S.; Sen, K. et al. Potentiality of mosambi (Citrus limetta) peel dust toward removal of $\mathrm{Cr}(\mathrm{VI})$ from aqueous solution: an optimization study. Appl Water Sci 2019, 9, 116. https://doi.org/10.1007/s13201-019-0997-6

4. Tanaka, T. Species problem in citrus: a critical study of wild and cultivated units of citrus, based upon field studies in their native homes. Revisio Auratiacearum 1994, 9, 115-117. 
5. Aguilar, C.; Rodriguez, R.; Gutierrez-Sanchez, G.; Augur, C.; Favela-Torres, E.; Prado-Barragan, L.A.; Ramirez-Coronel, A.; Coteras-Esquivel, J.C. Microbial Tannases: advances and perspectives. Appl. Microbiol. Biotechnol. 2007, 76, 47-59, https://doi.org/10.1007/s00253-007-1000-2

6. Rout, S.; Banerjee, R. Production of tannase under mSSF and its application in fruit juice debittering. Indian J Biotechnol. 2006, 5, 351-356.

7. Boczniewicz, J.B.; Zbigniew, G. Immobilization of Naringinase from Penicillium decumbens on Chitosan Microspheres for Debittering Grapefruit Juice. Molecules 2019, 24, 4234, https://doi.org//10.3390/molecules24234234.

8. Habelt, K.; Pittner, F. A rapid method for the determination of naringin, prunin, and naringin applied to the assay of naringinase. Anal Biochem. 1975, 134, 393-397, https://doi.org/10.1016/0003-2697(83)90314-7.

9. Puri, M.; Banerjee, U.C. Production, purification, and characterization of the debittering enzyme naringinase. Biotechnol Adv. 2000, 18, 207-217, https://doi.org/10.1016/S0734-9750(00)00034-3

10. Busto, M. D.; Meza, V.; Ortega, N.;Perez-Mateos, M. Immobilization of naringinase from Aspergillus niger CECT 2088 in poly (vinyl alcohol) cryogels for the debittering of juices. Food Chem. 2007, 104, 1177-1182, https://doi.org/10.1016/j.foodchem.2007.01.033.

11. Yadav, V.; Yadav, P. K.; Yadav, S.; Yadav, K. D. S. $\alpha-1-$ Rhamnosidase: A review. Process Biochem. 2010, 45, 1226-1235, https://doi.org/10.1016/j.procbio.2010.05.025.

12. Ono, M.; Tgsa, T.; Chibata, I. Preparation and properties of immobilized naringinase using tanninaminohexyl cellulose. Agric. Biol. Chem. 1978, 42, 1847-1853, https://doi.org/10.1080/00021369.1978.10863264.

13. Vila-Reala, H.; Alfaia, A.J.; Rosa, M.E.;Calado, A.R.; Ribeiro, M.H.L. An innovative sol-gel naringinase bioencapsulation process for glycosides hydrolysis. Process Biochem. 2010, 45, 841-850, https://doi.org/10.1016/j.procbio.2010.02.004.

14. Ribeiro, M.H. Naringinase: occurrence, characteristics, and applications. Appl. Microbiol. Biotechnol. 2011, 90, 1883-1895, https://doi.org/10.1007/s00253-011-3176-8.

15. de Lima, J.S.; Cabrera, M.P.; Casazza, A.A.; da Silva, M.F.; Perego, P.; de Carvalho, L.B.; Converti, A. Immobilization of Aspergillus ficuum tannase in calcium alginate beads and its application in the treatment of boldo (Peumus boldus) tea. International Journal of Biological Macromolecules 2018, 118, 470-476, https://doi.org/10.1016/j.foodres.2018.02.066 .

16. Puri, M.; Kalra, S. Purification and characterization of naringinase from a newly isolated strain of Aspergillus niger 1344 for the transformation of flavonoids. World Journal of Microbiology \& Biotechnology 2005, 21, 753-758, https://doi.org/10.1007/s11274-004-5488-7.

17. Da Costa, A.M.; Kadowaki, M.K.; Minozzo, M.C.; de Souza, C.G.M.;Boer, C.G.; Bracht, A.; Peralta, R.M. Production, purification and characterization of tannase from Aspergillus tamari. African Journal of Biotechnology 2012, 11, 391-398.

18. Davis, W.B. Determination of flavanones in citrus industry. Anal. Chem. 1947, 19, 476-478, https://doi.org/10.1021/ac60007a016

19. Elnashar, M.M. Review article: immobilized molecules using biomaterials and nanobiotechnology. J Biomater Nanobiotechnol. 2010, 1, 61-76, https://doi.org/10.4236/jbnb.2010.11008.

20. Srivastava, A.; Kar, R. Application of immobilized tannase from Aspergillus niger for the removal of tannin from myrobalan juice. Indian J. Microbiol. 2010, 50, 41-56, https://doi.org/10.1007/s12088-010-0029-6

21. Rangana, S. Analysis and quality control for fruit and vegetable products. Tata McGraw Hill Education Pvt. Ltd., New Delhi. 2010.

22. Sawhney, S. K. ; Singh, R. Estimation of ascorbic acid in lemon juice, Introductory practical Biochemistry. Narosa Publishing House, New Delhi. 2015; pp.104-105.

23. Makkar, H.P.S.; Bluemmel, M.; Borowy, N.K.; Becker, K. Gravimetric determination of tannins and their correlations with chemical and protein precipitation methods. Journal of Science Food Agriculture 1993, 61, 161-165, https://doi.org/10.1002/jsfa.2740610205.

24. Hagerman, A.E.; Butler, L.G. Protein precipitation method for the quantitative determination of tannins. J. Agric. Food Chem. 1978, 26, 809-812, https://doi.org/10.1021/jf60218a027.

25. Kumar, S.; Singh, V.; khadka, M.; Kohli, D. Effects of Microwave Heating and Conventional Pasteurization on Ascorbic Acid (Vitamin C), Tannin content, Total phenolic content of Amla (Phyllanthus emblica) Juice. Octa Journal of Biosciences. 2018, 6, 34-36.

26. Prakash, S.; Singhal, R.S.; Kulkarni, P.R. Enzymatic debittering of Indian grapefruit (Citrus paradise) juice. Journal of the Science of Food and Agriculture 2002, 82, 394-397, https://doi.org/10.1002/jsfa.1059.

27. Ghosh, U.; Gangopadhyay, H. Enzymatic, physicochemical and rheological behaviour of bael fruit pulp and juice. Indian Journal of Chemicl Technology 2002, 9, 123-126.

28. Mandakini, B.P.; Abhijit, B.D. Debittering of citrus fruit juice by naringinase of Penicillium purpurogenum. Int. J. Engg. Res. \& Sci. \& Tech. 2014, 3, 266-270.

29. El-Tanash, A.B.; Sherief, A.A.; Nour, A. Catalytic properties of immobilized tannase produced from Aspergillus aculeatus compared with the free enzyme. Brazilian Journal of Chemical Engineering 2011, 28, 381-391, https://doi.org/10.1590/S0104-66322011000300004. 
30. Escarpa, A.; González, M.C. Approach to the content of total extractable phenolic compounds from different food samples by comparison of chromatographic and spectrophotometric methods. Analytica Chimica Acta 2001, 427, 119-127, https://doi.org/10.1016/S0003-2670(00)01188-0.

31. Singleton, V.L.; Rossi, J.A. Colorimetric of total phenolics with phosphomolybdic-phosphotungstic acid reagent. American Journal of Enology and Viticulture 1965, 16, 144-158.

32. Cavia-Saiz, M.; Muñiz, P.; Ortega, N.; Busto, M.D. Effect of enzymatic debittering on antioxidant capacity and protective role against oxidative stress of grapefruit juice in comparison with adsorption on exchange resin. Journal Food Chemistry 2011, 125, 158-163, https://doi.org/10.1016/j.foodchem.2010.08.054.

33. Sawinder, K.; Sarkar, B.C.; Sharma, H.K.;Charanjiv, S. Response Surface Optimization of Conditions for the Clarification of Guava fruit Juice Using Commercial Enzyme. Journal of Food Process Engineering 2011, 34, 1298-1318, https://doi.org/10.1111/j.1745-4530.2009.00414.x. 